\title{
Empathy and Defender Role in Bullying at School: Student-Teacher Relationship as Mediator
}

\section{Charyna Ayu Rizkyanti ${ }^{1}$, Citra Wahyuni ${ }^{2}$, Shofia Alatas ${ }^{1}$}

\author{
${ }^{1}$ Faculty of Psychology, Universitas Pancasila, South of Jakarta \\ ${ }^{2}$ Department of Islamic Psychology, UIN Raden Intan Lampung, \\ Bandar Lampung
}

\section{Indonesia}

Correspondence: Faculty of Psychology Universitas Pancasila, Jakarta Selatan, Indonesia, 12640. E-mail: charyna@univpancasila.ac.id, citrawahyuni16@gmail.com, shofiyahalatas@gmail.com

(C) Universidad de Almería and Ilustre Colegio Oficial de la Psicología de Andalucía Oriental (Spain) 


\begin{abstract}
Introduction. Although much research has shown strong relationship between empathy and defender role, less is known about how student-teacher relationship mediated those variables. Our main hyphotesis was to reveal whether the student-teacher relationship could be mediating the effect of affective and cognitive empathy on the defender role in bullying at school.
\end{abstract}

Method. A total of 311 participants were selected from 2 secondary schools in south Jakarta. Students refer to grade 7-8 with ranged in age from 13 to 15 years $\left(M_{\text {age }}=13.64 ; S D\right.$ $=.713$ ). There were four instruments used: The Basic Empathy Scale to measure affective and cognitive empathy, Behaviors During Aggressive Episodes and Student Bystander Behavior Scale to measure defender role, and Student Per- ception of Affective Relationship with Teacher Scale.

Results. The results revealed both affective and cognitive empathy were found having a positive effect on defender role in bullying situation among junior high school stu- dents. However, cognitive empathy was found positively stronger on defender role rather than affective empathy. Furthermore, student-teacher relationship only partially mediated the effect both affective and cognitive empathy on defender role.

Discussion and Conclusion. These findings emphasized the urgency of comprehensive program to create defender by enhancing empathy and positive student-teacher rela- tionship to inhibit bullying behavior at schools.

Keywords: affective-cognitive empathy, defender, school bullying, student-teacher relationship. 


\section{Resumen}

Introducción. Aunque muchas investigaciones han mostrado una fuerte relación entre la empatía y el rol de defensor, se sabe menos acerca de cómo la relación alumno-maestro medió esas variables. Nuestra principal hipótesis fue revelar si la relación alumno-profesor podría estar mediando el efecto de la empatía afectiva y cognitiva sobre el papel defensor del acoso escolar.

Método. Se seleccionaron un total de 311 participantes de 2 escuelas secundarias en el sur de Yakarta. Los estudiantes se refieren a los grados 7-8 con edades comprendidas entre los 13 y los 15 años $($ Media $=13.64 ; S D=.713)$. Se utilizaron cuatro instrumentos: la escala de empatía básica para medir la empatía afectiva y cognitiva, las conductas durante episodios agresivos y la escala de conducta de los espectadores del estudiante para medir el rol de defensor y la Percepción del estudiante de la relación afectiva con la escala del maestro.

Resultados. Los resultados revelaron que la empatía tanto afectiva como cognitiva tiene un efecto positivo en el papel de defensor en situaciones de acoso entre los estudiantes de secundaria. Sin embargo, la empatía cognitiva se encontró positivamente más fuerte en el papel de defensor que en la empatía afectiva. Además, la relación alumno-maestro sólo medió parcialmente el efecto de la empatía tanto afectiva como cognitiva sobre el papel de defensor.

Discusión y Conclusion: Estos hallazgos enfatizaron la urgencia de un programa integral para crear defensores mejorando la empatía y la relación positiva alumno-maestro para inhibir el comportamiento de intimidación en las escuelas.

Palabras clave: empatía afectivo-cognitiva, defensor, acoso escolar, relación alumnomaestro. 


\section{Introduction}

Bullying is still being a worldwide problem including in Indonesia. The Plan International and International Center for Research on Women (ICRW) found 84\% children in Indonesia experienced violence at school (Qodar, 2015). Moreover, one of civil society organization, i.e. Yayasan Semai Jiwa Amini revealed around 67,9\% high school and 66,1\% secondary school students in big city such as Jakarta have become victims of bullying (Desiree, 2013) and these problems is still taking place

Bullying is a subtype of a different proactive aggression with a certain power imbalance between bullies and victim that occur over time, repeatedly (Solberg \& Olweus, 2003). Students who are being victims of bullying are not only targeted by offenders, but they are often disliked, isolated, and even rejected by other students in larger peer groups (Smith in Gini, Pozzoli, \& Bussey, 2014). This certainly has a negative impact on the physical and mental health of the victim, as well as on psychosocial adjustments (Card, Stucky, Sawalani, \& Little 2008). As it often occurs at school (Fekkes, Pijpers, \& Verloove-Vanhorick, 2005), the extent to which bul- lying takes place is not only harmed victims, but also the onlookers (Salmivalli, Lagerspetz, Bjorkqvist, Osterman, \& Kaukiainen, 1996), including peers who were merely witnessing bul- lying events can be also negatively influenced (Nishina \& Juvenon, 2005).

However, less is till known that students who witness the bullying episodes might put them in one position or role as participant. These participant roles (Salmivalli, 1999) have been identified as assistants are children who help the bullies; reinforces support the bullies (e.g., by laughing or cheering); passive bystanders/outsiders whom remain passive and try to avoid par- ticipating in bullying; and last, defenders, who try to help, comfort and support victims (Jungert, Piroddi, \& Thornberg, 2016). Among high school students in Indonesia, it was found that most of participants who witnessed bullying choose to avoid this situation, either by leaving or silently watching the event (Damanik and Djuwita, 2019). Their confession portrayed some rea- sons, such as unwillingness to be involved (61.4\%), did not know what to do $(61.3 \%)$ perceived that other students would also not do anything (60.4\%), and a few (10.4\%) stated for doing nothing since they considered it is as a normal thing.

When bullying took place, one role could make a difference for victims is the defenders. When students are being the defenders, they will strongly reject bullying, entertain and 
side with victims of bullying, and try to encourage other friends not to do bullying, even stop bully- ing perpetrations (Peets, Poyhonen, Juvenon, \& Salmivalli, 2015). Defender is also capable in dealing with bullying perpetrators with the aim of helping victims or seeking help from adults who can be very effective in ending bullying (Bellmore et al., 2012). In addition, their behavior is clearly anty-bullying (Salmivalli, 1999). Finally, there is a motivation that arises inside them to help victims which makes teens feel anxious when only being a passive observer (Jungert et al., 2016).

In Indonesia, Damanik and Djuwita (2019) have identified the behavior of bullying incidents among 138 first year college students, where the participants were asked to recall and retell their past experiences about bullying in school. In short, one of those findings revealed out of $69.6 \%$ participants who had witnessed bullying had chosen to be uninvolved. They were more likely to do nothing, either walking away from location, silently watching, or even enjoy- ing the event as something entertained them. This evidently shows how the defender role is rarely to be happened among adolescents who witnessed the bullying situation.

Several factors might influence children to become defenders in bullying situations, such as age, social status, empathy, family, gender, and self-efficacy (Bellmore, et al, 2012; Caravita, Blasio, \& Salmivalli, 2009; Thornberg \& Jungert, 2013; Valdés-Cuervo, et al. 2018). It was found that prosocial and defending pupils are high in empathy (Endresen \& Olweus, 2001), in other words, defenders are children who have the ability to understand the cognition and emotions of others (Gini in Correia \& Dalbert, 2008). Empathy could predict children's roles to be defender or outsider (Nickerson, Mele, \& Princiotta 2008). Research regarding defender behavior is more or less associated with empathy. Bellmore, Ma, You, \& Hughes (2012) study explained that boys who help victims or become defenders are those who have high empathy.

Empathy, the ability to recognize, understand, interpret, and anticipate the thoughts and behavior of others (Baron-Cohen et al. 2001) often falls in to two dimensions: cognitive and affective dimensions (Lawrence et al, 2004). Cognitive empathy is defined as an intellectual understanding of one's mental statues, while affective empathy is defined as having an appro- priate emotional response when dealing with another person's mental status. Individuals who can share and understand the emotional reactions of others due to aggressive behavior are proven to be able to inhibit the occurrence of negative behavior in the future. Low 
empathy might cause difficulty to interact with social environment, particularly in childhood, where low empathy is associated with poor peer relations, hostility, or violence (Findlay, Girardi, \& Coplan, 2006; Mayberry \& Espalage. 2007). Regarding violence behavior, it has postulated that bullying is closely related to low empathy (Jolliffe \& Farrington, 2006). Therefore, these main issues highlighted whether defender role is influenced by students' capability to distinguish between their own feeling and thought with others', yet, they could stand up for they who are being hurt.

The efforts of teachers or school staff to provide a supportive climate are being considered as a strategy to involve students in preventing bullying and threats of violence (Eliot, Cornell, Gregory, \& Fan, 2010). Teacher approval might motivate students to defend victims in bullying situation (Thornberg et al., 2012) since teachers are the most important resources to stop bullying event (Rodkin \& Hodges, 2003). By developing positive relationships with students, they might protect students from negative behaviors, particularly in bullying involvement (Wang, Swearer, Lembeck, Collins, \& Berry, 2015).

Student-teacher relationship which defined as a meaningful and developing emotional and relational connection between students and teachers as a result of prolonged interactions (Fraire, Longobardi, Prino, Sclavo, \& Settanni, 2013; Longobardi, Prino, Marengo, \& Settanni, 2016 in Longobardi, Iotti, Jungert, \& Settanni, 2018) is known to be vital for fostering students' interpersonal skills (Donohue, Perry, \& Weinstein, 2003). Students who consider both teachers and other school staffs support them are more likely to show a positive attitude by seeking help when there is bullying and threats of violence. It might be due to the power to influence the behavior of each agent, respectively (Stuhlman \& Pianta, 2002) Therefore, students tend not to engage in bad behavior when they have positive bonds and relationships with important people, one of which is the teacher in their lives (Wang et al., 2015).

Student-teacher relationship might bring along to the roles taken by students in bullying situation at school (Longobardi, Iotti, Jungert, \& Settani, 2018). Students who have positive, warm, caring, and supportive relationship with their teachers, they are being motivated to defend victims (Jungert et al., 2016; Thornberg, Wanstrom, Hong, \& Espelage, 2016). It is related with students' perception that either adult or teachers want those students to make intervention towards bullying situations (Thornberg et al., 2012). Students perceive that adults expect them to stop the ongoing bullying event. 
Empathy is considered as intrinsic motivation that might encourage students to take role as defender while bullying situation happened (Forsberg et al., 2014; Thornberg, 2010; Thornberg et al., 2012). However, students still need stronger support from teacher to convince that their behavior is considered as something right. The ability to feel others' emotion (affective empathy) and the ability to understand others' point of view (cognitive empathy) of the victim might direct the students to the source of mutually supportive and meaningful relationships, that is their teachers, both intellectually and socially. Finally, this situation will motivate stu- dents to defend victims of bullying.

This research highlights problems related to bullying have not been resolved up until now, including in Indonesia. Unlikely most research conducted in Indonesia, this research will not examine both bullies and victims whom were directly involved in bullying situations. The defender role, they who report incidents of bullying behavior to their teacher and tell the per- petrators to stop bullying the victims are often associated with students' empathy. Even though the relationship between empathy and bullying have been studied a lot, less is still known that any response given by students when viewing bullying events also might contribute to the continuation of the bullying process itself.

\section{Objectives and Hypotheses}

The objective of this study to examine that student-teacher relationship might mediate the effect of affective and cognitive empathy on defender role in bullying at school. We expected that the effect of affective and cognitive empathy on defender role would be especially strong when students-teacher relationship was positive.

\section{Method}

\section{Participants}

From a total sample of 350 participants, 311 students ( $43.4 \%$ boys; $56.6 \%$ girls) were selected by convenient sampling technique. They were $7^{\text {th }}(48.2 \%)$ and $8^{\text {th }}(51.8 \%)$ grade $\left(M_{\text {age }}=13.64 ; S D=.713\right)$ from 2 junior high schools and located in South Jakarta. Researchers did not include students from grade $9^{\text {th }}$ due to school preparation for final exam. All students filled in the questionnaires at their desk in classroom. Three researchers were present, reading the written instructions for each measure out loud and assisting students who need further help. 


\section{Instruments}

Empathy. Empathy was assessed by the self-report questionnaire The Basic Empathy Scale (BES) by Jolliffe and Farrington (2006). There are 20 items consisting of 9 items for measuring cognitive empathy, e.g., "I have difficulty guessing my friends' feelings" and 11 items for affective empathy, e.g., "It is difficult for me to understand when my friends feel $s a d "$. For each item, participants were asked to evaluate the extent to their agreement on a 4point scale $(1=$ strongly disagree, $2=$ disagree, $3=$ agree, $4=$ strongly agree $)$. There was 10 items valid in affective empathy, while cognitive empathy found 6 items valid. This analysis revealed that both dimensions showed a good were fited to the model. In empathy measurement, the affective empathy showed RMSEA $=0.037, \mathrm{GFI}=0.98\left(\chi^{2}=22.125, d f=24, p=\right.$ 0.08573 ), with factor loading range 0.49 - 0.81 , while the cognitive empathy showed RMSEA $=0.062, \mathrm{GFI}=0.99\left(\chi^{2}=13.09, d f=6, p=0.4169\right)$, with factor loading range $0.42-0.87$.

Student-Teacher Relationship. The Student-Teacher Relationship was measured by the Student Perception of Affective Relationship with Teacher Scale (SPARTS) developed by Koomen and Jellesma (2015). It was a self-report instrument consisting of 29 items which presented 3 dimensions identified as closeness (e.g., I feel relaxed with my teacher), conflict (e.g., My teacher treats me unfairly), and negative expectation (e.g., I wish my teacher would listen to me better if I have something to say or tell). This measuring instrument has been adapted according to response categories. Using a 4-point Likert scale ( $1=$ strongly disagree, 2 = disagree, 3 = agree, 4 = strongly agree). There were 16 items valid out of 29 items, consisting of closeness dimensions with 3 items, negative expectation with 3 items, and conflict with 10 items. This data were fitted to the model, where the value of factor loading range from 0.36-1.00 and estimated reliability (ER) values of 0.909, $R M S E A=0.049, G F I=0.94$ $\left(\chi^{2}=146.19, d f=84, p=0.00003\right)$.

Defender Role. In this study, the role of Defender in the bullying situation was measured by adapted two instruments. The first one is Behaviors During Aggressive Episodes was adapted by Gini, Pozzoli, and Busses (2014) (e.g., "I defend the classmates who are hit or attacked hard"). In their study, they were adapted Behaviors During Aggressive Episodes instrument from two previous research (Pozzoli and Gini 2010; Pozzoli et al. 2012), but they add a new item so that we decided to use the instrument that adapted by Gini, Pozzoli, and Busses (2014) as a reference. The second instrument is The Student Bystander Behavior Scale 
developed by Thornberg and Jungert (2013) (e.g., "I tried to get the bullies to stop"). We adapted the two instruments and combined both of them to measure the role of Defender. Out of 6 items, there was 1 invalid item. Participants responded using a 4-point Likert scale $(4=$ Never, 3 = Rarely, 2 = Often, 1 = Always). This analysis also revealed that the data were fitted to the model, where factor loading values ranging from $0.435-0.847, R M S E A=0.054$, $G F I=0.994\left(\chi^{2}=9.533, d f=5, p=0.090\right)$.

\section{Procedure}

The pilot study was carried out by giving those instruments which already adapted to a different and a smaller number of samples with the same characteristics according to predetermined criteria. The sample's criteria of this study is students aged 13-15 years old who are currently registered as active students in junior high schools located in the area of South Jakarta. This pilot study stage was carried out on 9-11 May 2019 to 66 junior high school students. School principals and teachers authorized the participation of their students in this study. Prior to data collection, individual consent to participate had also been carried out. The data collection phase was carried out on May 13-17 2019 using a questionnaire. There were 311 out of 350 participants' answers to be processed.

\section{Datal Analysis}

A Confirmatory factor analysis was performed by means of structural equation modelling with the Mplus software (Mplus 3.0) for validity test. For testing the hypothesis, we used the conditional effect analysis technique to test the simple mediation model using PROCESS Hayes macro IBM SPSS Statistics version 21.

\section{Results}

Base don Table 1, the results of the regression analysis revealed that affective empathy significantly pos- itively predicted defender role by $3.4 \% ; F(1,309)=10,836, p<0.01, R^{2}=$ 0.034 with a coeffi- cient of $B=0.265, p=0.001$. It indicated that the higher the affective empathy students have, the higher the probability to be defender. Next, student-teacher relationship also depicted posi- tively effects on defender behavior by $5.8 \% ; F(1,309)=19,066$, $p<0.01$ and $R^{2}=0.058$, with a coefficient of $B=0.138, p=0.000$. These results indicated that the better the relationships between students and teachers, students are more likely to show defender behavior. Further more, the results of this simple regression analysis revealed that 
students' affective empathy and their relationship with teacher have a positive effect toward defender behavior. Therefore, further analysis was needed to determine the relationship of affective empathy, defender behavior, and student - teacher relationship.

Table 1. Regression Analysis of Affective Empathy and Student-Teacher Relationship on Defender Behavior

\begin{tabular}{lcccccc}
\hline \multicolumn{1}{c}{$\begin{array}{c}\text { Independent } \\
\text { Variable }\end{array}$} & $R^{2}$ & \multicolumn{2}{c}{$\begin{array}{c}\text { Unstandardized } \\
\text { coeffiecents }\end{array}$} & $\begin{array}{c}\text { Standardized } \\
\text { Coeffiecients }\end{array}$ & & $F$ \\
\cline { 3 - 6 } & & $\beta$ & $S E$ & $\mathrm{~B}$ & & \\
\hline $\begin{array}{l}\text { Affective Empathy } \\
\text { Student- teacher Rela- }\end{array}$ & 0.034 & 0.265 & 0.080 & 0.184 & 10.836 & 0.001 \\
\begin{tabular}{l} 
tionship \\
\hline
\end{tabular} & 0.058 & 0.138 & 0.032 & 0.241 & 19.066 & 0.000 \\
\end{tabular}

Note: The dependent variable is defender

The analysis revealed that affective empathy has a strongly positive effect on defender behavior. The mediating role of student-teacher relationship in the effect of empathy towards defender role was partially confirmed (95\% CI: .0122, $p=.1070)$; effect size $=.0504$. In other words, affective empathy still has a direct effect on defender behavior (See Figure 1 for details).

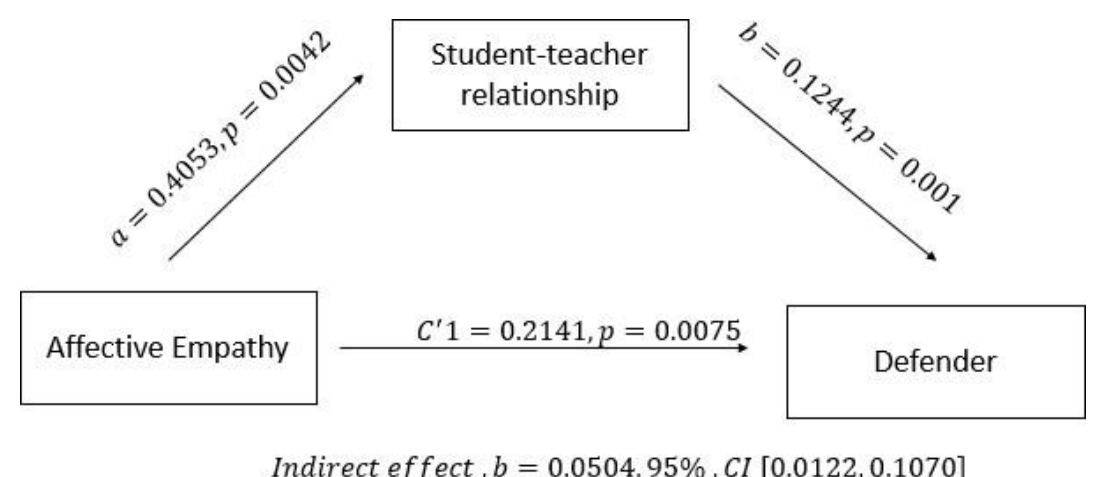

Figure 1. Mediation Analysis of Student Teacher Relationship in Relationship Affective Empathy on Defender.

Slightly different from the previous result, this analysis showed that cognitive empathy positively effects the defender role, and it was found higher than affective empathy by $12.5 \%$; $F(1,309)=43,179, p<0.01$ and $R^{2}=0.12$ with a coefficient of $B=0.369, p=0.000$. It showed the higher the cognitive empathy student have, the higher the probability to be defender $F(1,309)=43,179, p<0.01$ and $R^{2}=0.123$. Student-teacher relationship also positively ef- 
fects the defender role by $5.8 \% ; F(1,309)=19,066, p<0.01$ and $R^{2}=0.058$ with a coefficient of $B=0.138, p=0.000$. These results indicated that the better the relationship between students and teachers, they were more likely to show defender behavior. For simple regression analysis, it was found that students' cognitive empathy and their relationship with teacher have a positive effect toward defender behavior. Next, analysis was needed to examine the effect of cognitive empathy relationship towards defender behavior, with student - teacher relationship as mediator.

Table 2. Regression Analysis of Cognitive Empathy (CE) and Student-Teacher Relationship (STR) on Defender Behavior

\begin{tabular}{|c|c|c|c|c|c|c|}
\hline \multirow{2}{*}{$\begin{array}{c}\text { Independent } \\
\text { Variable }\end{array}$} & \multirow[t]{2}{*}{$R^{2}$} & \multicolumn{2}{|c|}{$\begin{array}{l}\text { Unstandardized } \\
\text { coeffiecents }\end{array}$} & \multirow{2}{*}{$\begin{array}{c}\text { Standardized } \\
\text { Coeffiecients } \\
\text { B } \\
\end{array}$} & \multirow[t]{2}{*}{$F$} & \multirow[t]{2}{*}{$p$} \\
\hline & & $\beta$ & $S E$ & & & \\
\hline Cognitive Empathy & 0.125 & 0.477 & 0.072 & 0.354 & 44.210 & 0.000 \\
\hline Student- teacher & 0.058 & 0.138 & 0.032 & 0.241 & 19.066 & 0.000 \\
\hline Relationship & & & & & & \\
\hline
\end{tabular}

Note: The dependent variable is defender

The analysis revealed that cognitive empathy still had a strongly positive effect on defender behavior. The mediating role of student-teacher relationship as mediator between cognitive empathy and defender role was partially confirmed (95\% CI: .04404, p=.000); effect size $=.0368$. It is indicated that cognitive empathy still has a direct effect on defender behavior (See Figure 2 for details).

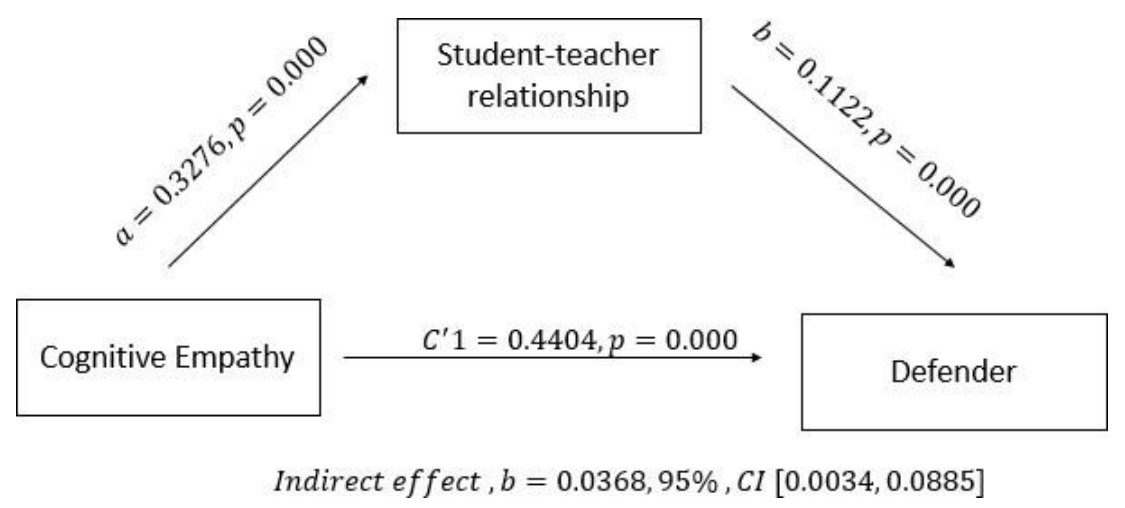

Figure 2. Mediation Analysis of Student Teacher Relationship in Relationship Cognitive Empathy on Defender. 


\section{Discussion and conclusion}

Since the research of defender role is still vary, this research focused in early adolescents as previous study found that $20-30 \%$ preadolescent and adolescent sample encouraged the bully, either as assistants or reinforcers (Salmivalli, 1996). In addition, 20-30\% of adolescents silently witness bullying and remain aside. We hypothesized that empathy might effect positively to defender behavior, which both affective and cognitive components have specific contribution. The first results confirmed that affective and cognitive empathy represent two distinct constructs, which have unique associations with bullying and defending behaviors.

Compared to prior research, these findings suggested cognitive empathy shows bigger contribution than affective empathy on defender behavior among students. These results are not consistent with several previous studies (Barchia \& Bussey, 2011; Caravita et., 2009; Ploeg, Kretschmer, Salmivalli, \& Veenstra, 2017; Rizkyanti, Murty, \& Paramaharta, 2020) which supported affective empathy was predicted on defending behavior, though it was not the sole factor. In other words, previous studies explained that affective empathy was considered more important for defending victims rather than cognitive empathy. Despite those psychosocial difficulties, some of students who took roles as defender could not keep silent due to the big urge within. How students feel the emotions of victims not merely by perceiving what they are feeling, but by imagining the vic- tims' position, thus, it triggers them to speak and to defend.

The greater cognitive empathy was related to noticing bullying events and also accepting responsibility to intervene (Fredrick, Jenkins, \& Ray, 2020). The ability to take other's perspective made the students can distinguish conflict from bullying so that it can determine their role as a defender when looking at bullying behavior. Based on Joo, Kim, Kim, Carney, and Chatters (2020) perspective taking was positively associated with telling behavior of witnesses, while empathic concern was found to have no association with telling behavior.

The second aim of this study was to examine whether student-teacher relationship mediated between empathy (affective and cognitive) and defender behavior in bullying situations among students. Therefore, the current study also highlighted the urgency of teacher's role since they can influence in motivating students to act in a helpful manner. Our study gives important insight where empathy, particularly affective empathy can predict students' defend- 
er behavior through the mechanisms of student-teacher relationship. This finding shows while students could share emotion to the victims, then they could feel the teachers want them to help and intervene bullying event. Research also has showed that the close relationship between students and teachers tends to have personal motivation to defend bullies victims (Iotti, Thornberg, Longobardi, \& Jungert, 2020). When this situation had happened, those students have been in defender role.

Previous study by Caravita and Cillessen (2012) found that a high status as socially preferred might inhibit bullying and promote defending. Students who are being socially preferred may have such support feelings when they stand up for the victimized peer against bullies (Juvonen \& Galvan, 2008). Since defenders demonstrate dominant behavior (Meter \& Card, 2015) due to their highly popularity, they dare to take a stance against bullying (Caravita et al., 2009). Therefore, student-teacher relationship should be strengthened through incorporated peer group on enhancing defending behavior in bullying situations at school. Victim defending behaviors were significantly positively associated with connectedness and resources, suggesting that students' positive experiences with their school were associated with helpful and pro-social responses to witnessing bullying. This suggests that students who feel more connected to their school social environment may be more likely to want to help end bullying when they witness it (Bistrong, Bottiani, \& Bradshaw, 2019). Resources, closeness and support from the school will encourage students to defend their friends who are being bullied (Morin, Bradshaw, \& Kush, 2018). Since teachers are considered as the most important resources to stop bullying event at school setting (Rodkin \& Hodges, 2003), their approval might motivate students to defend victims in bullying situation (Thornberg et al., 2012). This result is congruent with Jungert et al. (2016), which showed that warm and caring student-teacher relationship were positively associated with defending victims and with autonomous motivation to defend victims.

Overall, the results of this study suggest that student-teacher relationship only partially mediates both affective and cognitive empathy toward the role of defender. In other words, affective and cognitive empathy can directly influence students' roles as defenders. Regarding with the developmental psychology framework, top dog phenomenon in early adolescence stage (Santrock, 2019) implies that younger students begin to follow some prominent behaviors of the older, including in the context of the role of participants in bullying situation. Due to the type of schools participated in this research was public school, it could produce differ- 
ent result considering student-teacher relationship if we compare to private middle schools. For example, large number of students in public school might lead some difficulties for teachers to pay attention on their students in detail (Jahrir, 2017). Students who are in a class with the fewer number of students receive more frequent contact with the teacher and are more emotionally positive, teachers in this class are observed to be more sensitive (Pianta, Hamre, $\&$ Stuhlman, 2003). Meanwhile, when students engaged in group activities with a large number of the group, children had less contact with the teacher than when in the small groups (Pianta, Hamre, \& Stuhlman, 2003). This condition may disturb the students' concentration due to fully teacher's attention is difficult to get for each student.

While almost previous research have emphasized the importance of the affective component of empathy in inhibiting aggressive behavior (Jolliffe \& Farrington, 2006), these findings provide empathy research with empirical support by showing that cognitive empathy is more likely influence defender behavior than affective empathy. The affective empathy shows bigger contribution towards defender behavior while there is warm and positive relationship between teacher and students. Notwithstanding, the present study emphasizes the importance of differentiating affective empathy from cognitive empathy in order to evaluate the defender behavior among students. Although the currents study revealed relevant findings, it has some limitations. As it was based on only two schools, it is not sufficient for its result to be generalized. Ideally, this research should be replicated in a larger number of schools. In addition, it was also based entirely on self-report measuring, thus, other methods of data collection (e.g., observer rating, peer nomination, or other report) would be useful in future research. Therefore, further investigations are needed to evaluate other school strategies, setting, or climate that may contribute to the effect of empathy on defender behavior among early teenagers.

Other contextual factors that might be contributed to the effect of empathy on defender behavior among early teenagers are self-efficacy, personal experience, peer-relationship, and teacher's empathy. It might necessary to include the self-efficacy factor considering that both outsider and defender have empathy but the defender have a high score of self-efficacy (Gini, Albiero, Benelli, \& Altoe, 2008). Not only self-efficacy but personal experience of being a victim also might increase someone's chances to become defender, individuals who have experience of being victims are expected to have more empathy for victims of bullying so that it will increase the defender behavior (Epps, Park, Huston, \& Ripke, 2005). The personal experience factor of being a victim of bullying has an effect on defender behavior (Bistrong, Botti- 
ani, \& Bradshaw, 2019). Peer-relationship also might have a contribution to the student when they decide to intervene and help the victim or not. Pozzoli, Gini, and Vieno (2012) found that students who lack closeness with their friends tend to be reluctant to help friends who are bullied (victim). Last, teacher's empathy might be an interesting factor to see in the next research, remembered that teacher's empathy has a correlation with teachers' positive attitudes and behavior towards bullying that occurs in schools (notice, interpret as an emergency, take responsibility, know what to do, and intervene bullying) (Eldridge \& Jenkins, 2019). Further research should examine these factors as well as possible interaction effects between them.

\section{References}

Barchia, K., \& Bussey, K. (2011). Predictors of student defenders of peer aggression victims: Empathy and social cognitive factors. International Journal of Behavioral Development, 35, 289-297.

Baron-Cohen, S., Wheelwright, S., Hill, J., Raste, Y., \& Plumb, I. (2001). The 'reading the mind in the eyes' test revised version: A study with normal adults, and adults with asperger syndrome or high-functioning autism. Journal of Child Psychology \& Psychiatry \& Allied Disciplines, 42, 241-251. doi: 10.1017/S0021963001006643.

Bellmore, A., Ma, T.-L., You, J., \& Hughes, M. (2012). A two-method investigation of early adolescents' responses upon witnessing peer victimization in school. Journal of Adolescence, 35, 1265-1276.

Bistrong, E., Bottiani, J. H., \& Bradshaw, C. P. (2019). Youth reactions to bullying: Exploring the factors associated with students' willingness to intervene. Journal of school violence, 18(4), 522-535.

Caravita, S. C. S. \& Cillessen, A. H. N. (2012). Agentic or communal? Develop- mental differ- ences in the associations among interpersonal goals, popularity, and bullying. Social Development, 2, 376-395.

Caravita, S. C. S., Di Blasio, P., \& Salmivalli, C. (2009). Unique and interactive effects of empathy and social status on involvement in bullying. Social Development, 18, 140163. Retrived from: http://dx.doi.org/10.1111/j_.1467-9507.2008.00465.x.

Card, N. A., Stucky, B. D., Sawalani, G. M. \& Little, T. D. (2008). Direct and indirect aggression during childhood and adolescence: A meta-analytic review of gender differences, intercorrelations, and relations to maladjustment. Child Development, 79(5), 1185-1229. 
Correia, I., \& Dalbert, C. (2008). School bullying: Belief in a personal just world of bullies, victims, and defenders. European Psychologist, 13(4), 248-254. doi: 10.1027/10169040.13.4.248.

Damanik, G. N. A. \& Djuwita, R. (2019). Gambaran perundungan pada siswa tingkat SMA di Indonesia. Jurnal Psikogenesis, 7(1), 28-40.

Desiree. (2013). Bullying di pesantren: Studi deskriptif di pesantren " $X$ " Depok. (Unpublished Thesis). FISIP UI.

Donohue, K. M., Perry, K. E., \& Weinstein, R. S. (2003). Teachers' classroom practices and children's rejection by their peers. Journal of Applied Developmental Psychology, 24(1), 91-118. doi: 10.1016/S0193-3973(03)00026-1.

Eldridge, M. A., \& Jenkins, L. N. (2019). The Bystander Intervention Model: Teacher Intervention in Traditional and Cyber Bullying. International Journal of Bullying Prevention, 1-11.

Eliot, M., Cornell, D., Gregory, A. \& Fan, X. (2010). Supportive school climate and student willingness to seek help for bullying and threats of violence. Journal of School Psychology, 48(6), 533-553.

Epps, S. R., Park, S. E., Huston, A. C., \& Ripke, M. (2005). A scale of positive social behaviors. In K. A. Moore \& L. H. Lippman (Eds.), What do children need to flourish? The search institure series on developmentally attentive community and society (vol. 3, pp. 163-179). Boston, MA: Springer.

Endresen, I. M. \& Olweus, D. (2001). Self-reported empathy in Norwegian adolescents: sexdifferences, age trends, and relationship to bullying. In D. Stipek, \& A. Bohart (Eds.), Constructive and destructive behavior. Implications for family, school, society (pp. 147 165). Washington, DC: American Psychological Association.

Fekkes, M., Pijpers, F. \& Verloove-Vanhorick, S. (2005). Bullying: who does what, when and where? Involvement of children, teachers and parents in bullying behavior. Health Education Research, 20, 81-91.

Findlay, L. C., Girardi, A., \& Coplan, R. J. (2006). Links between empathy, social behavior, and social understanding in early childhood. Early Childhood Research Quarterly, 21(3), 347-359. doi: 10.1016/j.ecresq.2006.07.009.

Forsberg, C., Thornberg, R., \& Samuelsson, M. (2014). Bystanders to bullying: Fourth- to seventh-grade students' perspectives on their reactions. Research Papers in Education, $29,557-576$ 
Fraire, M., Longobardi, C., Prino, L. V Sclavo, E. \& Settanni, M. (2013). Examining the student-teacher relationship scale in the Italian context: A factorial validity study. Electronic Journal of Research in Educational Psychology,11, 851-882. doi: 10.25115/ejrep.31.1591.

Fredrick, S. S., Jenkins, L. N., \& Ray, K. (2020). Dimensions of empathy and bystander intervention in bullying in elementary school. Journal of school psychology, 79, 31-42.

Gini, G., Albiero, P., Benelli, B., \& Altoe, G. (2008). Determinants of adolescents' active defending and passive bystanding behavior in bullying. Journal of Adolescence, 31(1), 93-105. doi:10.1016/j.adolescence.2007.05.002.

Gini, G., Pozzoli, T., Vieno, A. \& Lenzi, M. (2014). Bullying victimization at school and headache: A meta-analysis of observational studies. Headache: Journal of Head and Face Pain, 54(6), 976-986. doi:10.1111/head.12344.

Gini, G., Pozzoli, T., \& Bussey, K. (2015). The role of individual and collective moral disengagement in peer aggression and bystanding: A multilevel analysis. Journal of $A b$ normal Child Psychology, 43(3), 441-452.

Iotti, N. O., Thornberg, R., Longobardi, C., \& Jungert, T. (2020, February). Early Adolescents' Emotional and Behavioral Difficulties, Student-Teacher Relationships, and Motivation to Defend in Bullying Incidents. In Child \& Youth Care Forum (Vol. 49, No. 1, pp. 59-75). Springer US.

Jahrir, A. S. (2017, April 2). Perbedaan sekolah swasta dan sekolah negeri. Kompasiana. Retrived from: https://www.kompasiana.com/andisahtianijah-rir/58e0e37b2f9373ed2 74e1fb3/perbedaan-sekolah-swasta-dan-sekolah-negeri.

Jolliffe, D \& Farrington, D. P. (2006). Development and validation of the Basic Empathy Scale. Journal of Adolelescence, 29, 589-611. doi:10.1016/j.adolescence.2005.08.010.

Joo, H., Kim, I., Kim, S. R., Carney, J. V., \& Chatters, S. J. (2020). Why witnesses of bullying tell: Individual and interpersonal factors. Children and Youth Services Review, 116, 105198 .

Jungert, T., Piroddi, B. \& Thornberg. (2016). Early adolescents' motivations to defend victims in school bullying and their perceptions of student-teacher relationship: A selfdetermination theory approach. Journal of Adolescence, 53, 75-90.

Juvonen J, Galvan A. (2008). Peer contagion in involuntary social groups: Lessons from research on bullying. In: Prinstein M, Dodge K, editors. Peer influence processes among youth. (pp. 225-244). New York: Guilford Press. 
Koomen, H. M. \& Jellesma, F. C. (2015). Can closeness, conflict, and dependency be used to characterize students' perceptions of the affective relationship with their teacher? Testing a new child measure in middle childhood. British Journal of Educational Psychology, 85(4), 479-497.

Lambe, L. J., Hudson, C. C., Craig, W. M., \& Pepler, D. J. (2017). Does defending come with a cost? Examining the psychosocial correlates of defending behaviour among bystanders of bullying in a Canadian sample. Child Abuse \& Neglect, 65, 112-123. doi: 10.1016/j.chiabu.2017.01.012.

Lawrence, E. J., Shaw, P., Baker, D., Baron-Cohen, S., \& David, A. S. (2004). Measuring empathy: Reliability and validity of the empathy quotient. Psychological Medicine, 34(5), 911-920. doi: 10.1017/S0033291703001624.

Longobardi, C., Prino, L. E., Marengo, D., \& Settanni, M. (2016). Student-teacher relationships as a protective factor for school adjustment during the transition from middle to high school. Frontiers in Psychology,7, 1-9. doi: 10.3389/fpsyg.2016.01988.

Longobardi, C., Iotti, N.O., Jungert, T. \& Settani., M. (2018). Student-teacher relationship and bullying: The role of student social status. Journal of Adolescence, 63, 1-10.

Mayberry, M. L., \& Espelage, D. L. (2007). Associations among empathy, social competence, $\&$ reactive/rroactive aggression subtypes. Journal of youth and adolescence, 36(6),787798.doi:10.1007/s10964-006-9113-y.

Meter, D. J., \& Card, N. A. (2015). Defenders of victims of peer aggression: Interdependence theory and an exploration of individual, interpersonal, and contextual effects on the defender participant role. Developmental Review, 38, 222-240. doi: 10.1016/j.dr.2015.08.001.

Morin, H. K., Bradshaw, C. P., \& Kush, J. M. (2018). Personal and contextual factors associated with cyberbullying victimization: The role of psychological, social, and academic adjustment. Journal of School Psychology, 70, 74-88.

Nickerson, A. B., Mele, D., \& Princiotta, D. (2008). Attachment and empathy as predictors of roles as defenders or outsiders in bullying interactions. Journal of School Psychology, 46(6), 687-703. doi: 10.1016/j.jsp.2008.06.002.

Nishina, A., \& Juvonen, J. (2005). Daily reports of witnessing and experiencing peer harassment in middle school. Child Development, 76, 435-450.

Peets, K., Pöyhönen, V., Juvonen, J., \& Salmivalli, C. (2015). Classroom norms of bullying alter the degree to which children defend in response to their affective empathy and power. Developmental Psychology, 51(7), 913-920. 
Pianta, R. C., Hamre, B., \& Stuhlman, M. (2003). Relationships between teachers and children. Handbook of Psychology. 7, 199-234.

Ploeg, R., Kretschmer, T., Salmivalli, C. \& Veenstra, R. (2017). Defending victims: What does it take to intervene in bullying and how is it rewarded by peers? Journal of School Psy-chology, 65(1-10).

Pozzoli, T., Gini, G., \& Vieno, A. (2012). The role of individual correlates and class norms in defending and passive bystanding behavior in bullying: A multilevel analysis. Child Development, 83(6), 1917-1931. doi:10.1111/j.1467- 8624.2012.01831.x.

Qodar, N. (2015, Maret 15). Survei ICRW: 84\% Anak indonesia alami kekerasan di sekolah. Liputan6.com. Retrieved from: http://www.liputan6.com/news/read/2191106/surveiicrw-84-anakindonesia alami-kekerasan-di-sekolah.

Rizkyanti, C. A., Murty, A. I. \& Paramaharta, N. R. (2020). Empati afektif: Pengaruh keterlibatan orang tua terhadap peran defender remaja dalam perundungan di sekolah. Jurnal Ilmu Keluarga dan Konsumen, 13(3), 250-261.

Rodkin, P. C. \& Hodges, E. V. E. (2003). Bullies and victims in the peer ecology: Four questions for psychologists and school professionals. School Psychology Review, 32(3), 384400.

Salmivalli, C., Lagerspetz, K., Björkqvist, K., Österman, K., \& Kaukiainen, A. (1996). Bullying as a group process: Participant roles and their relations to social status within the group. Aggressive Behavior, 22, 1-15.

Salmivalli, C. (1999). Participant role approach to school bullying: Implications for interventions. Journal of Adolescence, 22 (4), 453-459.

Santrock, J. W. (2019). Human development. $17^{\text {th }}$ Ed. New York: McGraw Hill.

Solberg, M. E., \& Olweus, D. (2003). Prevalence estimation of school bullying with the O1weus bully/victim questionnaire. Aggressive Behavior, 29, 239-268.

Stuhlman, M.W. \& Pianta, R.C. (2002). Teachers' narratives about their relationship with chil dren: Association woth behavior in classrooms. School Psychology Review, 31(2), 148163.

Thornberg, R. (2010). A student in distress: Moral frames and bystander behavior in school. Elementary School Journal, 110, 585-608.

Thornberg, R., Tenenbaum, L., Varjas, K., Meyers, J., Jungert, T., \& Vanegas, G. (2012). Bystander motivation in bullying incidents: To intervene or not to intervene?. Western Jour- nal of Emergency Medicine, 13(3), 247. 
Thornberg, R., \& Jungert, T. (2013). Bystander behavior in bullying situations: Basic moral sensitivity, moral disengagement and defender self-efficacy. Journal of Adolescence, 36, 475-483.

Thornberg, R., Wänströma, L., Hong, J. S., \& Espelage, D. (2016). Individual and class sociomoral influences on how to act as a bystander in school bullying situations. In Paper presented at the 44th Congress of Nordic Educational Research Association at Helsinki, Fin- land, 9e11 March, 2016.

Valdés-Cuervo, A. A., Martinez-Ferrer, B. \& Carlos-Martinez, E. A. (2018). The role of teaching practices in the prevention of school violence among peers. Revista de Psicodidactica, 23(1), 33-38.

Wang, C., Swearer, S. M., Lembeck, P., Collins, A., \& Berry, B. (2015). Teachers matter: An examination of student-teacher relationships, attitudes toward bullying, and bullying behavior. Journal of Applied School Psychology, 31(3), 219-238.

Received: $25-05-2020$

Accepted: 28-02-2021 